\title{
Isolation and characterization chitosan from varied crab shell
}

\author{
KR Ningtyas ${ }^{*}$, M Muslihudin ${ }^{2}, \mathrm{~V}$ Elsyana $^{3}$ \\ ${ }^{1}$ Agro-industrial Product Development, Politeknik Negeri Lampung, Bandar \\ Lampung, Indonesia \\ ${ }^{2}$ Food Technology, Politeknik Negeri Lampung, Bandar Lampung, Indonesia \\ ${ }^{3}$ Industrial Chemical Engineering Technology, Politeknik Negeri Lampung, Bandar \\ Lampung, Indonesia
}

*Corresponding author: ningtyas@polinela.ac.id

\begin{abstract}
Crab shells chitosan processing consists of 3 steps, the process is deproteinization, demineralization, and deacetylation. This study aims to produce chitosan with a high yield as an alternative to natural adsorbents and coagulants. This research was conducted using three different raw materials for crab shells, namely mangrove crab shells (K1), small crab shells (K2), and kappa crab shells (K3). In this study, a demineralization process was carried out on dried crab shells using strong acids. Furthermore, deproteination is carried out using a strong base to obtain chitin and deacetylation with a strong base to produce chitosan. The results of research carried out observations including moisture content, ash content, solubility, and yield. The results of the isolation of the crab shell chitosan obtained the chitosan yields of $31 \%$, $32.2 \%$, and $24.5 \%$, respectively.
\end{abstract}

\section{Introduction}

Mud crab (Scylla serrata) Is one of the Indonesian important economic value fisheries commodities. $\mathrm{Crab}$ production in Indonesia increases every year, especially in the form of canned products with a total production of 4,000 tons per year. In 2014, the export volume of small crab and crab has increased to 28,091 tons with a value of US $\$ 414.3$ million. This condition causes an increase in the waste produced by crab products, especially solid waste in the form of crab shells. Data shows that 1,000 tons of crab shell waste are produced per year (Trisnawati et al., 2013). Discarding these byproducts creates problems such as the underutilization of a huge amount of nutrients and the disposal of such huge quantities of highly polluting organic matter contributing to major environmental and economic problems in both developed and developing countries.

Chitosan is a polymer derived from chitin which is found in many invertebrates (Akmarina dan Sriwidodo, 2016). Chitosan has good biocompatibility, biodegradation and bioresorbable properties, and non-toxicity material (Afriani et al., 2016). Chitosan has the molecular formula [C6H11NO4]n and the chemical formula poly (2-amino-2-dioxy- $\beta$-D-Glucose). Chitosan is in the form of yellowishwhite flakes, odorless and tasteless.

Chitosan is not also isolated from invertebrate animals such as Arthropoda sp, Mollusca sp, Coelenterata sp, Annelida sp, Nematoda sp, and some fungi groups but also found in fish gills, trachea, intestinal walls, and squid skin. The main source of chitosan is the shells of Crustaceae sp, namely shrimp, lobsters, crabs, and other shelled animals, especially those of marine animals. Berger 
et al. (2004) chitosan can be applied in various fields of modern industry, for example, pharmaceutical, biochemical, cosmetics, food industry, and textile industry.

Processing of crab shells into chitosan can be carried out through three processes, namely deproteination, demineralization, and deacetylation. Deproteination will remove protein residue from crab meat, demineralization with low acid concentration will reduce mineral content and generate chitin, and deacetylation will remove the acetyl group by heating the crab shell in a strongly alkaline solution. Furthermore, deacetylation removes acetyl groups from chitin through heating in a strongly alkaline solution with high concentrations (Yunizal et al., 2001). This study high yield chitosan from varied species of crab shells as an alternative to natural adsorbents and coagulants.

\section{Material and Method}

The tools used in this study were Erlenmeyer, beaker glass, measuring cup, hotplate, magnetic stirrer, oven, blender, sieve, filter paper, drop pipette, volume pipette, mortar, centrifuge. The materials used are crab shells, $\mathrm{NaOH}, \mathrm{HCl}$, distilled water,

This research was conducted using three different raw materials for crab shells, namely mangrove crab shells (K1), small crab shells (K2), and kappa crab shells (K3). In this study, a demineralization process was carried out on dried crab shells using strong acids. Furthermore, deproteination is carried out using a strong base to obtain chitin and deacetylation with a strong base to produce chitosan. The results of research carried out observations including moisture content, ash content, solubility, and yield of chitosan.

The initial stage is the isolation of chitosan from crab shells. Isolation of chitosan was carried out in three stages, namely demineralization, deproteination, and deacetylation. Isolation of chitosan using crab shells begins with the preparation of the raw materials by washing the crab shells using running water and drying them in the sun then reducing the size using a blender. Furthermore, the crab shells were soaked in $1 \mathrm{~N} \mathrm{HCl}$ solution with soaking time for 60 hours. After that, demineralization was carried out with $1 \mathrm{~N} \mathrm{HCl}$, at $90^{\circ} \mathrm{C}$ for 60 minutes. Then neutralization was carried out using distilled water until the $\mathrm{pH}$ was neutral. The drying result of the demineralization process is deproteinated with $3 \mathrm{~N} \mathrm{NaOH}$, at $90^{\circ} \mathrm{C}$ for 60 minutes, and neutralization is carried out again to neutral $\mathrm{pH}$ to obtain chitin. After that, it was dried and deacetylated with $50 \% \mathrm{NaOH}$, at a temperature of $140^{\circ} \mathrm{C}$ for 60 minutes and chitosan was obtained.

\section{Result and Discussion}

The results of the stages of demineralization, deproteination, and deacetylation of chitosan can be seen in table 1.

Table 1. Crab shell chitosan isolation results

\begin{tabular}{ccccc}
\hline Sample & Raw Material $(\mathrm{g})$ & Demineralisasi $(\mathrm{g})$ & Deproteinasi $(\mathrm{g})$ & Deasetilasi $(\mathrm{g})$ \\
\hline K1 & 100 & 57,4 & 50,5 & 38,5 \\
\hline K2 & 100 & 60.6 & 50,4 & 44,0 \\
\hline K3 & 100 & 59,0 & 50,4 & 40,1 \\
\hline
\end{tabular}

The transformation of chitin into chitosan is through a deacetylation process. Deacetylation is a process to remove the acetyl group $\left(-\mathrm{COCH}_{3}\right)$ from chitin using an alkaline solution to turn it into an amine group $\left(-\mathrm{NH}_{2}\right)$. Chitin has a long crystalline structure with strong hydrogen bonds between nitrogen atoms and carboxylate groups in adjacent chains (Muzzarelli, 1986). At the end of the deacetylation stage, the yield of chitosan will be produced against the chitin produced from the deproteination stage. Yield is the number of percentages of product content contained in a material, the yield produced from a substance or material depends on the quality of the material used, the higher the yield produced, the better the quality of the material used. The yield calculation is done by weighing the chitosan that has been produced, then divided by the amount of material (chitin) used. 
The yield of chitosan from research results as well as water and protein content tests can be seen in Table 2 .

Table 2. Yield, water content, and an ash content of chitosan

\begin{tabular}{cccc}
\hline Sample & Chitosan (\%) & Water content (\%) & Ash content (\%) \\
\hline K1 & 76,23 & 2,6035 & 51,7592 \\
\hline K2 & 87,30 & 2,6631 & 53,4136 \\
\hline K3 & 79,56 & 2,3237 & 50,8352 \\
\hline
\end{tabular}

The yield of chitosan which was produced from the deacetylation stage ranged from $76.23 \%$ to $87.30 \%$. The yield of chitosan is determined based on the dry weight of chitosan produced against dry raw materials. The deacetylation process is the process of forming chitosan from chitin using $\mathrm{NaOH}$ to replace the acetamide group with an amino group. According to Hudson (Khoerunnisa et al., 2007) > $50 \%$ deacetylated chitin is called chitosan. From the research, it was found that the deacetylation degree of chitin from crab shells ranged from $76.23 \%$ to $87.30 \%$, so it can be considered as chitosan.

Water content is the percentage of water content contained in a material. Protan Biopolymer sets the quality standard for the water content of chitosan is $\leq 10 \%$ (Bastaman, 1989 in (Aji, 2012). The water content value of chitosan from the research was known to range from $2.3237 \%$ to $2.6631 \%$. This value is lower than the quality standard set, so the chitosan produced is dry and good. The amount of water content in chitosan is undesirable for use in various fields because it will affect resistance to attack by microorganisms (Rochmawati et al., 2015). (Suptijah et al., 2012) stated that the water content was low due to good drying methods. (Hossain \& Iqbal, 2013) suggest that the amount of water content is influenced by the drying process, drying time, the amount of chitosan dried, the area of the place for drying, and the means of drying.

Ash content is a parameter to determine which minerals are contained in chitosan and which can affect solubility, result in low viscosity, or can affect the characteristics of the final product (Arafat et al., 2018). Ash content is a parameter to determine the minerals contained in chitosan. According to Nugroho et al (2011), the ash content is a measure of the success of the demineralization process in the isolation of chitin from its raw materials. Ash content can be used as a quality parameter of chitosan because the lower the value of the ash content, the higher the purity level of the chitosan, and vice versa. (Antonino et al., 2017) stated that low ash content indicates low mineral content. The ash content obtained in crab shell chitosan was still quite high, ranging from $50.8352 \%$ to $53.4136 \%$. The results of the ash content obtained from the study showed that the processes of demineralization, deproteinization, and deacetylation reactions in this study were not effective in reducing the components of inorganic compounds. According to Suptijah et al. (2011) factors that have an influence on chitosan mineral content are the quality of water used during the chitosan neutralization process and the effectiveness of the demineralization process carried out. (Islam et al., 2011)) a good washing process, affects the ash content and minerals that have been released from the material will bind to the solvent and can be wasted with water.

The solubility of chitosan in acetic acid is one of the main parameters in the quality assessment standards of chitosan. According to Rochima, the higher the solubility of chitosan in acetic acid $2 \%$, the better the chitosan quality is (Rochima et al. 2004 in (Prisiska, 2012)). The resulting chitosan has imperfect solubility in $2 \%$ acetic acid. Solubility was observed by comparing the clarity of the chitosan solution with the clarity of the solvent. The results showed that the solubility of chitosan in acetic acid $2 \%$ could not dissolve completely, this can be seen in the presence of chitosan deposits in acetic acid solution.

The particle size will affect the solubility of chitosan, the smaller the particle size, the easier the chitosan will dissolve in the solvent (Muhamad et al., 2018). According to Dunn, the characteristics of chitosan which can only be dissolved in dilute acid solutions, such as acetic acid, are possible because the carboxyl groups in acetic acid will facilitate the dissolution of chitosan due to the hydrogen 
interaction between the carboxyl groups and the amine groups of chitosan (Dunn et al. 1997 in (Dompeipen et al., 2016).

\section{Conclusion}

The yield of chitosan ranged from $76.23 \%$ to $87.30 \%$, the largest yield was from a small crab shell. The water content value of chitosan results from the research was better than the standard set, which ranged from $2.3237 \%$ to $2.6631 \%$. The ash content ranges from $50.8352 \%$ to $53.4136 \%$ and has poor solubility.

\section{References}

Afriani, Y., Fadli, A., Maulana, S., \& Karina, I. (2016). Sintesis , Kinetika Reaksi dan Aplikasi Kitin dari Cangkang Udang: Review. October, 1-2.

Aji, A. (2012). Jurnal Teknologi Kimia Unimal. lim(November), 79-90.

Akmarina, C. A., \& Sriwidodo. (2016). Artikel Review: Aplikasi Kitosan dalam Bidang Farmasetik. Farmaka, 14(2), 318-330.

Antonino, R. S. C. M. D. Q., Fook, B. R. P. L., Lima, V. A. D. O., Rached, R. Í. D. F., Lima, E. P. N., Lima, R. J. D. S., Covas, C. A. P., \& Fook, M. V. L. (2017). Preparation and characterization of chitosan obtained from shells of shrimp (Litopenaeus vannamei Boone). Marine Drugs, 15(5), 112. https://doi.org/10.3390/md15050141

Arafat, A., Samad, S. A., Masum, S. M., \& M, M. (2018). Preparation and characterization of chitosan from Indonesian Tambak Lorok shrimp shell waste and crab shell waste. Pakistan Journal of Nutrition, 17(9), 446-453. https://doi.org/10.3923/pjn.2018.446.453

Dompeipen, E. J., Kaimudin, M., Dewa, R. P., Riset, B., Ambon, I., Cengkeh, J. K., \& Ambon, B. M. (2016). Isolasi kitin dan kitosan dari limbah kulit udang. 092.

Hossain, M. ., \& Iqbal, A. (2013). Production and characterization of Chitosan from shrimp shells waste. AACL Bioflux, 6(4), 339-344. https://doi.org/10.3329/jbau.v12i1.21405

Islam, M., Masum, S., Rahman, M. M., Islam, A., \& Shaikh, a a. (2011). Preparation of Chitosan from Shrimp Shell and Investigation of Its Properties. International Journal of Basic \& Applied Sciences, February, 77-80.

Khoerunnisa, F., Santosa, S. J., \& Kunarti, E. S. (2007). Kajian Adsorpsi Ag(S2o3)23- Dalam Limbah Fotografi Pada Adsorben Kitin Dan Asam Humat Terimobilisasi Pada Kitin. Jurnal Pengajaran Matematika Dan Ilmu Pengetahuan Alam, 9(2), 58. https://doi.org/10.18269/jpmipa.v9i2.327

Muhamad, L., Nadia, H., \& Huli, L. O. (2018). Pembuatan Dan Karakterisasi Kitosan Dari Cangkang Rajungan ( Portunus pelagicus ) Asal Sulawesi Tenggara Laode Muhamad Hazairin Nadia*, La Ode Huli, Laode Abdul Rajab Nadia. 1(2), 77-84.

Prisiska, F. (2012). The Influence of Chitosan on Elongation and Tensile Strength Characteristic of Wound Healing Biomembrane Abstract. 1-14.

Rochmawati, Z. N., Nabila, F., \& Ainurrohmah, C. (2015). Karakterisasi Kitosan Yang Diisolasi Dari Cangkang Internal Cumi-Cumi.

Suptijah, P., Jacoeb, A. M., Deviyanti, N., \& Pendahuluan, I. (2012). Litopenaeus vannamei ). III(1).

Trisnawati, E., Andesti, D., \& Saleh, A. (2013). Dengan Variasi Lama Pengawetan. 19(2), 17-26. 